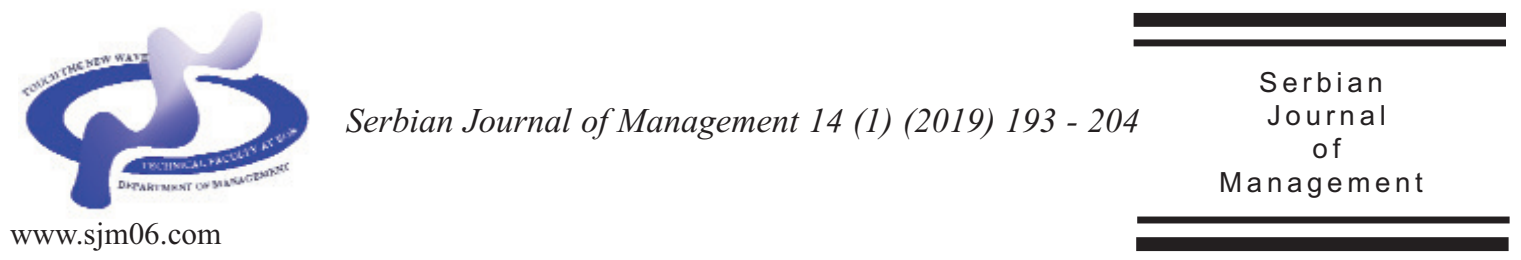

\title{
MEASURING CORPORATE SOCIAL PERFORMANCE
}

\author{
Le Ha Nhu Thao ${ }^{a}$, Doan Ngoc Phi Anh ${ }^{b}$ and Jolán Velenceic

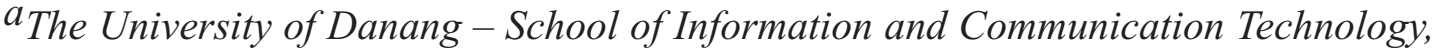 \\ 41 Le Duan, Hai Chau, Danang, Vietnam

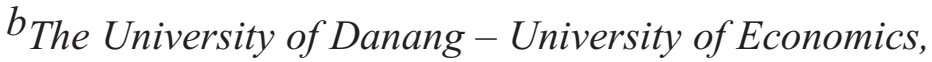 \\ 71 Ngu Hanh Son, Son Tra, Danang, Vietnam \\ ${ }^{c}$ Óbuda University, Keleti Faculty of Business and Management, \\ 1084 Tavaszmezo str.7, Budapest, Hungary
}

(Received 21 June 2018; accepted 10 September 2018)

\begin{abstract}
Business and researchers have paid increasingly more attention to corporate social responsibility (CSR) disclosure in term of their sustainable reports. These disclosures supply information for not only managers in strategic decision-making, but also other stakeholders in measuring and evaluating corporate social performance (CSP). Although the development of literature on CSR disclosure, the CSR's measurement is not yet unified because of different perspectives and methodology. The question is how to measure CSP through analyzing CSR disclosure. This paper aims to present the theoretical background of CSR and CSR disclosure. Based on the conceptual framework, the research exposes the drivers of CSR reporting as well as debates prior research on CSR disclosure and its consequences. Furthermore, a measurement method of CSP proposed building on CSR disclosure index in this paper. It devotes to enrich the corporate social responsibility reporting literature, offers implications for practice as well as outlines promising avenues for future research, especially in the differences of CSR disclosure among different countries.
\end{abstract}

Keywords: corporate social responsibility, corporate social performance, disclosure index

\section{INTRODUCTION}

The increasing of the government's restrictions on social and environmental issues, the demand of consumers for organic products, and strict requirement from investors put more pressure on businesses. As a result, businesses not only aim at maximizing profit, but also pursue social responsibility, especially in term of the

* Corresponding author: Ihnthao@sict.udn.vn

DOI: $10.5937 /$ sjm14-18009 
disclosure. Therefore, issues related to the disclosure of corporate social responsibility such as sustainability reporting, social accountability, social accounting, social responsibility disclosure, attracts much attention from researchers as well as businesses. Since the CSR reporting award scheme was established by the Association of Chartered Certified Accountants (ACCA), along with the development of "triple bottom line reporting" (social, environmental and economic) (Elkington, 1998) and Global Reporting Initiative (GRI) have motivated various enterprises in making social statements (Boesso \& Kumar, 2007). This report was started in the UK, but later expanded to other European countries and others, such as USA, Canada, Australia, New Zealand, Pakistan, Hong Kong, Singapore, Sri Lanka and Malaysia. In addition, the increasingly popular corporate governance debate raises a number of demands for improving transparency and ethics in business. Although corporate social disclosures have not yet strongly developed as compared to financial reports, this is one of the bases for assessing the performance of corporate social and environmental activities.

Relatively prior work, many authors have applied to the content analysis method to evaluate the corporate social performance through information disclosure. This measurement method is mainly used to investigate the motivations for social and environmental activities based on quantitative and qualitative analyses for the cases of developed and developing countries. However, there are certain limitations to each study. The question of how to measure the corporate social performance through information disclosure still have not yet found the answer.
This article aims to introduce the background of CSR and CSR disclosure. Furthermore, the paper provides the theoretical foundations underlying these concepts. In the following section, the article analyses previous studies on content analysis methods through the publication of information on social responsibility. A number of future research recommendations will be provided in the final section of the paper.

\section{CORPORATE SOCIAL RESPONSIBILITY}

CSR is more concerned with the correlation of political, cultural and economic systems. According to Friedman (1970) the success of society significantly depends on the specialization of the organization (or system) with the exclusive aim of maximizing shareholder returns (protect their property rights). Managers use enterprise resources for non-profit activities considered to be economically divergent and paid "taxed illegally". On the contrary, Freeman (1984) argued that the economic model and organizational specialization were not Friedman's argument. Furthermore, in terms of "legitimacy", businesses are limited in their ability to operate in economic roles, but they need to expand their role in other areas, taking into account the interests of other stakeholders.

According to Carroll (1979), social responsibility is understood as the accountability to satisfy the expectations and obligations that society poses to the business at a given time. The business responsibility is categorized into hierarchy model in which economic responsibility is the foundation and following by legal, ethical, and 
philanthropy. Another discussion by Frank \& Armandi (1981) gives a view on social responsibility based on Maslow's pyramid model. Social responsibility is a full realization of the needs within and outside the organization, and is at the highest position in the business needs pyramid.

In an analysis by Dahlsrud (2008), based on the results of the content analysis of 37 different definitions of social responsibility, he presented a general concept of social responsibility. Businesses have always had an impact on the economy, society and the environment, have close relationships with government, customers or shareholders, and comply with the law. Thus, social responsibility consists of five aspects: economic, social, environmental, voluntariness, and stakeholder (Dahlsrud, 2008).

In summary, the definition of social responsibility is understood in a variety of ways, depending on the case. In the context of increasing globalization, challenging business environment, rules, principles, and influences of stakeholders, the selection of aspects to implement social responsibility should be taken into consideration. CSR should be consistent in accordance with the business strategy and development of the enterprises.

\section{CSR DISCLOSURE}

\subsection{Definition}

Activities demonstrating corporate social responsibility should be communicated to stakeholders through disclosure. In a definition on the stakeholder perspective, Gray et al., (2001) argued that the disclosure of information about social responsibility is the preparation and publication of information about social and environmental activities and interactions with employees, communities, customers, and other stakeholders of the business. The information provided in financial information or usually a combination of non-financial quantitative, narrative, and qualitative information. Social information may be aimed at different purposes but should provide clear and verified information. This definition is clarity and adequacy based on the debate on transparency, democracy, and accountability that should be seen as the underlying goal of social accounting.

\subsection{Categories}

According to Boesso \& Kumar (2007), CSR disclosure can be divided into four categories:

- Private information from Management Audits: primarily provides information for internal decision making.

- Private information from external sources: examples of auditor or market research.

- Public "external social audits": performed by independent auditors such as Social Accounting Ltd, which helps to increase the transparency and clarity of the report.

- Public self-reporting by the organization: The annual report is published on the company's website.

The fourth type of report is comprehensive and attracts the attention of many social accountants today.

\subsection{Theoretical framework}

A number of prior research has applied different theories to demonstrate on CSR 
disclosure such as legitimacy theory, stakeholder theory, institutional theory, political theory, or agency theory. However, the single analytic of each theory still disclosed some limitation. This research combines the two most common theories, including legitimacy theory and stakeholder theory for the purpose of their sustainability to CSR disclosure.

\subsubsection{Legitimacy theory}

The Legitimacy theory argues that organizations implement information disclosure to demonstrate their legitimacy to society. Enterprises need to adapt to the expectations of society to be legitimate in the changeable social phenomena over time (Deegan, 2002).

The theory of legitimacy thus indicates that enterprises seek to secure a constant supply of resources and actions to maintain legitimacy (Dowling \& Pfeffer, 1975). These actions include the disclosure of information to assure the target or control of entities as well as links to legitimate organizations (Deegan et al., 2002). In order to ensure the compliance according to social changes, businesses must change and adapt their development strategies, and more importantly, publish them to the target audience (Deegan, 2002). The legitimacy theory has been widely used in previous empirical studies on CSR disclosure (Deegan et al., 2002; Gray et al., 1995; Lu \& Abeysekera, 2014; Patten, 1991; Reverte, 2009; Tagesson et al., 2009).

Despite of the population of legitimacy theory, it still reveals some limitations that need to be developed. For example, this theory takes legal safeguards into consideration, however, it does not mention the most successful media changing stakeholder perception and the most influenced stakeholder by information disclosure. In essence, this theory does not address the notion of "society" in a broad orientation whereas society consists of many objects with different powers. Meanwhile, stakeholder theory refers to different audiences with the different point of view and powers in society. Stakeholder theory will help solve the problem when it comes to addressing the importance of the various objects in society to the business.

\subsubsection{Stakeholder theory}

Although the issue of stakeholders has been mentioned since the 1960s, Freeman (1984) has provided the most complete idea of the stakeholders including those who affect or are affected by the business operations. For example, stakeholders are customers, employees, suppliers, governments, pressure groups, and others outside the society.

Based on previous studies of stakeholders, Berman et al., (1999) proposed two models of different stakeholders. The first model, the strategic management model for strategic stakeholders, shows that companies are interested in stakeholders because they are aware of the benefits of improving financial performance. The second model is an internal engagement showing stakeholders' relationship management, which is based on ethical commitments rather than the desire for maximizing profits (Berman et al., 1999). Freeman's definition of the stakeholders noted above also suggests a two-way relationship between the organization and the stakeholders. First, stakeholders can influence the business, which is related to the first model of Berman and the second factor, 
in which stakeholders are affected by the company's activities, is related to the second model of Berman. Relative prior studies have conducted the stakeholder theory (Choi et al., 2010; Gallardo-Vázquez \& SanchezHernandez, 2014; Gray et al., 1995; Jo \& Harjoto, 2012; Lu \& Abeysekera, 2014; Reverte, 2009; Roberts, 1992; Saleh et al., 2011; Tagesson et al., 2009).

The stakeholder theory has emphasized that businesses not only focus on economic benefits but also pay attention to the interests of the stakeholders. On this basis, the corporate social disclosure is a way to express the business's concern to the interests of stakeholders.

\section{MEASURING CORPORATE SOCIAL PERFORMANCE}

It is understood that social responsibility cannot identify a range of social actions in corporate behaviour without measuring performance (Gallardo-Vázquez \& SanchezHernandez, 2014). Many previous research has conducted content analyse to evaluate corporate social performance as can be seen in Table 1.
Literature review show that the analysis on CSR disclosure is categorized in different ways. For instance, Belal \& Momin (2009) allocated CSR research into three perspectives (1) content, level, and determinant of CSR disclosure (2) research in managerial perspectives (3) stakeholders' perspectives. Mathews (1997) indicated timeline structure to analyse CSR disclosure. Gray et al. (2001) concentrated on (1) topic and dimension of CSR information (2) CSR disclosure quantity. This research discusses on three main aspects to analyse CSR measurement including reliability of disclosure, disclosure quantity, and disclosure quality.

\subsection{Reliability of disclosure}

The most important issue to be considered in the research using the content analysis methodology is the reliability of the reports. In the study by Milne \& Adler (1999), they have shown a few reports that clearly state reliability and provide definitions and tools for identifying and classifying public content as well as representing the consistency and accuracy of the report. In addition, they have described the methods or tools used to assess

Table 1. Dimensions and measurement of CSR disclosure

\begin{tabular}{|c|c|c|c|c|}
\hline \multirow{2}{*}{ Authors } & \multirow{2}{*}{ Country } & \multirow{2}{*}{ CSR dimension } & \multicolumn{2}{|c|}{ Measurement } \\
\hline & & & Quantity & Quality \\
\hline Deegan \& Rankin (1996) & Australia & Environment & $\mathrm{X}$ & \\
\hline Adams et al. (1998) & 6 European countries & Environment and human resources & $X$ & \\
\hline Neu et al. (1998) & Canada & Environment & $\mathrm{X}$ & \\
\hline Tsang (1998) & Singapore & Total CSR disclosure & $\mathrm{X}$ & \\
\hline Cormier \& Magnan (2003) & France & Environment & $X$ & \\
\hline Cormier et al. (2005) & German & Environment & & $X$ \\
\hline Haniffa \& Cooke (2005) & Malaysia & Total CSR disclosure & $\mathrm{X}$ & \\
\hline Branco \& Rodrigues (2008) & Portugal & Total CSR disclosure & $X$ & \\
\hline Esa \& Mohd Ghazali (2012) & Malaysia & Total CSR disclosure & $X$ & \\
\hline Khan et al. (2013) & Bangladesh & Total CSR disclosure & $X$ & \\
\hline Lu \& Abeysekera (2014) & China & Social and environment & $X$ & $\mathrm{X}$ \\
\hline Hoang et al. (2016) & Vietnam & Total CSR disclosure & $X$ & $\mathrm{X}$ \\
\hline
\end{tabular}

Note: Total CSR disclosure includes environment, human resource, product and consumer, community 
the reliability of coding in reports (Milne \& Adler, 1999).

Annual reports are most frequently used in the content analysis because these reports are highly reliable (Tilt, 1994). Based on information published in annual reports, researchers have easy access to analytical sources. However, Robert (1991) argued that focusing entirely on annual reports would lead to an incomplete picture of the business. Therefore, some other studies use the annual report and some other documents to carry out the content analysis for analysing corporate social responsibility disclosure. Harte \& Owen (1991) used the annual report and environmental report, while Buhr (1998) used information in annual reports, stock market information and on environmental reports. In addition, the use of various documents may lead to some difficulties in research. First, in the case of large companies, they often publish a variety of information about social and environmental activities on their annual reports, magazines, and advertisements. This leads to the inability to collect all the data in the variety of these companies' documents. Furthermore, the information in other documents may not be stored in the official source of the business. Therefore, data may not be comprehensive enough to collect information from other sources than the annual report (Unerman, 2000).

\subsection{Measuring disclosure quantity}

In order to measure the number of CSR disclosure, along with identifying the materials used for analysis, quantitative methods also affect the results. In previous studies, the authors used different methods to determine the quantity of disclosure such as the number of characters, the number of words, the number of sentences, the number of pages, the percentage of pages containing the social and environmental information published on the analytical materials, or the percentage of corporate social responsibility disclosure on the total number of publications (Adams et al., 1998; Branco \& Rodrigues, 2008; Cormier \& Magnan, 2003; Deegan \& Rankin, 1996; Esa \& Ghazali, 2012; Haniffa \& Cooke, 2005; Hoang et al., 2016; Khan et al., 2013; Lu \& Abeysekera, 2014; Neu et al., 1998; Tsang, 1998). One underlying hypothesis in these studies is that the number of the social responsibility publication reflects the importance of

Table 2. Measurement method of CSRD quantity

\begin{tabular}{|c|c|c|c|c|c|c|c|}
\hline \multirow[b]{2}{*}{ Authors } & \multirow[b]{2}{*}{ Year } & \multicolumn{6}{|c|}{ Measurement method } \\
\hline & & $\begin{array}{c}\text { No. of } \\
\text { documents }\end{array}$ & $\begin{array}{l}\text { No. of } \\
\text { words }\end{array}$ & $\begin{array}{c}\text { No. of } \\
\text { sentences }\end{array}$ & $\begin{array}{l}\text { No. of } \\
\text { pages }\end{array}$ & $\begin{array}{c}\text { No. of } \\
\text { disclosures }\end{array}$ & $\begin{array}{c}\% \text { of } \\
\text { pages }\end{array}$ \\
\hline Deegan \& Rankin & 1996 & & $\mathrm{X}$ & & $\mathrm{X}$ & & \\
\hline Adams et al. & 1998 & & & & & & $\mathrm{X}$ \\
\hline Buhr & 1998 & & & $\mathrm{X}$ & & & \\
\hline Neu et al. & 1998 & $\mathrm{X}$ & $\mathrm{X}$ & & & & \\
\hline Tsang & 1998 & $\mathrm{X}$ & & $\mathrm{X}$ & & & \\
\hline Haniffa \& Cooke & 2005 & & $\mathrm{X}$ & & & & \\
\hline Said et al. & 2009 & & & & & $X$ & \\
\hline Esa \& Ghazali & 2012 & & & & & $\mathrm{X}$ & \\
\hline Khan et al. & 2013 & & & & & $\mathrm{X}$ & \\
\hline Lu \& Abeysekera & 2014 & & & & & $\mathrm{X}$ & \\
\hline Hoang et al. & 2016 & & & & & $\mathrm{X}$ & \\
\hline
\end{tabular}


published content (Neu et al., 1998). Different measurement techniques result in different analysis findings. The higher consistency of the approach, the better ability to compare with other studies (Table 2).

In terms of the method to count the disclosure quantity, word counting is considered as the highest detail. Meanwhile, the method of measuring the number of sentences can be more accurately calculated (Tsang, 1998) and the semantic expressions of the content are more accurate than the individual case of the word. However, the use of sentences as a unit of measurement may not be appropriate for grammatical differences. Besides, the number of words and sentences can only be used in the case of reports in narrative form, which is difficult to use for reports that provide information on data, charts, and images. While this information is recognized as an effective way of communicating to have a summary of the report. In this case, counting the number of words or sentences is not appropriate to reflect the full content of the information published.

In the study of Unerman (2000), he argued that the measurement of the number of characters, number of words or number of sentences could eliminate the case of charts or the title of the chart. Measuring by percentage of the content of page can solve this problem. However, according to Hackston \& Milne (1996), the results are similar in the case of the number of sentences and percentages in a page. In other words, measuring percentage in a page is based on subjective point of view in the measurement process. In recent studies, in order to increase the objectivity of the classification and selection of content disclosure standards, researchers have relied on international guidelines such as GRI, SA
8000, or AA1000. Moreover, other studies (Esa \& Ghazali, 2012; Hoang et al., 2016; Khan et al., 2013; Lu \& Abeysekera, 2014; Said et al., 2009) used a number of disclosures as a measure of disclosures quantity. The use of this measure minimizes the disadvantages of counting the number of words, sentences, or pages of previous studies.

\subsection{Measuring disclosure quality}

Disclosure of information on social responsibility is based not only on what is published but on how is published (Guthrie \& Parker, 1989). Relatively previous works corporate social responsibility disclosure, authors also pay attention to the quality of information published through the quality assessment of each published item and the quality of types of publication.

CSR is a multidimensional concept that consists of a variety of content, depending on the content and purpose of the analysis, the researchers can choose different items to evaluate the corporate social responsibility. The researchers assessed each item of social responsibility as having the equal value in the analysis of many studies (Cormier et al., 2005; Esa \& Ghazali, 2012; Haniffa \& Cooke, 2005; Said et al., 2009). By contrast, some others debate that the importance of each dimension in CSR concept is not the same, and they differently affect the business operation and stakeholders. Therefore, when analysing the CSR disclosure, the researchers are interested in the importance of item disclosure quality and type of disclosure quality. Lu \& Abeysekera (2014) evaluated the quality of information relating to each aspect of social responsibility published in the annual report of Chinese enterprises. They do a survey of twelve 
different target groups in order to evaluate 121 social, economic and environmental aspects according to GRI. Meanwhile, Hoang et al. (2016) analysed in a social aspect based on GRI, assessed the importance of relevance to the content of workers, products, community activities, human rights. Assessing the importance of this content, the research has asked stakeholders such as employees, clients, volunteer organizations, and lawyers.

In addition to the quality of each content analysed, research is also concerned with the quality of disclosures' types. While there are some views that appreciate the form of disclosure including detailed descriptive information, metrics, and numbers expressing monetary values (Hoang et al., 2016). Other studies argue that different forms of publication differ depending on the viewpoint of the parties involved. Thus, many authors have combined the evaluation of the quality of information disclosure to evaluate the disclosure of social information (Clarkson et al., 2008; Toms, 2002). Combined measurement of quantity, quality of content and quality of published information considered more comprehensive than those that based on quantitative information.

\section{CONCLUSION}

Regarding to previous work on corporate social responsibility disclosure, research has increasingly applied the comprehensive and objective analysis of information dissemination through a three-dimensional approach, including quantity, quality of item disclosure and quality of type disclosure. Consequently, the indicators of information disclosure are more accurate and more objective about corporate social responsibility. However, the extant literature reveals that the scale of measurement is not homogeneous in the contents and formula. Furthermore, the difference and the comparison between different industries have not mentioned and the corporate social responsibility index is unweighted in various sectors. Besides, the research has been focused more on developing countries than developing countries, especially research on the quality of information disclosure.

The future research could be conducted to build up the weighted index of corporate social responsibility disclosure evaluating the quantity and quality of information in different industries. The quantitative measurement is followed the number of disclosing based on the measurement scale, including three dimensions such as economic, environment, and society, in which, the interfere of these three contents should be mentioned to evaluate the sustainable development of business. The quality measurement could be evaluated by stakeholders of business in different sectors such as customers, employees or community in order to guarantee the objective of the research. Moreover, the model of research in developed countries should be captured in developing countries to make comparison between different countries and building the standardize index for different countries.

The research on building weighted index of corporate social responsibility can be used in the analysis of corporate social performance and corporate social responsibility impact on firm performance or corporate governance.

Acknowledgement:This research is funded by Funds for Science and Technology Development of the University of Danang under grant number B2016 - DNA - 19 - TT. 


\title{
МЕРЕЊЕ КОРПОРАТИВНИХ ДРУШТВЕНИХ ПЕРФОРМАНСИ
}

\author{
Le Ha Nhu Thao, Doan Ngoc Phi Anh, Jolán Velencei
}

\section{Извод}

Све више пажње се посвећује корпоративној друштвеној одговорности предузећа (КДО), од стране пословних људи али и истраживача, у смислу објављивања и праћења изештаја о одрживости. Овај вид извештавања пружа информацију, не само руководиоцима у стратешком одлучивању, већ и другим заинтересованим странама у мерењу и процени корпоративних друштвених перформанси (КДП) предузећа. Иако се литературна база развија, засновано на резултатима истраживања КДО, само мерење КДО-а још увек није унифицирано због различитих перспектива и примене различите методологије. Питање је како мерити КДП кроз анализу КДО извештаја. Овај рад има за циљ да представи теоријску основу КДО и КДО анализе. На основу концептуалног оквира, истраживање открива основе КДО извештавања, као и дискусију преходних истраживања зснованих на КДО извештајима, као и њиховим последицама. Поред тога, анализирана метода мерења КДП-а, доводи до предлога за формирање КДО индекса извештавања. Овај рад је посвећен прегледу и допуни истраживачке литературе из области корпоративне друштвене одговорности. Такође, нуди могућност импликације у пракси кроз објашњење потенцијалних могућности будућих истраживања, посебно у анализи разлика између КДО резултата у различитим земљама.

Кључне речи: корпоративна друштвена одговорност, корпоративне друштвене перформансе, индекс извештавања

\section{References}

Adams, C.A., Hill, W.Y., \& Roberts, C.B. (1998). Corporate social reporting practices in western europe: Legitimating corporate behaviour? British Accounting Review, 30 (1), 1-21.

Belal, A.R, \& Momin, M. (2009). Corporate social reporting (CSR) in emerging economies: A review and future direction. Research in Accounting in Emerging Economies, 9, 119-143.

Berman, S.L., Wicks, A.C., Kotha, S., \& Jones, T.M. (1999). Does Stakeholder Orientation Matter? The Relationship Between Stakeholder Management Models and Firm Financial Performance. Academy of Management Journal, 42 (5), 488-506.

Boesso, G., \& Kumar, K. (2007). Drivers of corporate voluntary disclosure.
Accounting, Auditing \& Accountability Journal, 20 (1), 269-296,

Branco, M.C., \& Rodrigues, L.L. (2008). Factors influencing social responsibility disclosure by Portuguese companies. Journal of Business Ethics, 83(4), 685-701.

Buhr, N. (1998). Environmental performance, legislation and annual report disclosure: the case of acid rain and Falconbridge. Accounting, Auditing \& Accountability Journal, 11 (2), 163-190.

Carroll, A.B. (1979). Three-Dimensional Conceptual Model of Corporate Performance. Academy of Management Review, 4 (4), 497-505.

Choi, J.S., Kwak, Y.M., \& Choe, C. (2010). Corporate social responsibility and corporate financial performance: Evidence from Korea. Australian Journal of Management, 35 (3), 291-311. 
Clarkson, P.M., Li, Y., Richardson, G.D., \& Vasvari, F.P. (2008). Revisiting the relation between environmental performance and environmental disclosure: An empirical analysis. Accounting, Organizations and Society, 33 (4-5), 303-327.

Cormier, D., \& Magnan, M. (2003). Environmental reporting management: A continenal European perspective. Journal of Accounting and Public Policy, 22(1), 43-62.

Cormier, D., Magnan, M., \& Velthoven, B. Van. (2005). Environmental Disclosure Quality In Large German Companies: Economic Incentives, Public Pressures or Institutional Conditions? Denis Cormier École des sciences de la gestion Université du Québec à Montréal Michel Magnan The Lawrence Bloomberg Chair in. European Accounting Review, 14(1), 3-39.

Dahlsrud, A. (2008). How Corporate Social Responsibility is Defined: an Analysis of 37 Definitions. Corporate Social Responsibility and Environmental Management, 13(November 2006), 1-13.

Deegan, C. (2002). Introduction the legitimising effect of social and environmental disclosures - a theoretical foundation. Accounting, Auditing \& Accountability Journal, 15 (3), 282-311.

Deegan, C., \& Rankin, M. (1996). Do Australian companies report environmental news objectively? Accounting, Auditing \& Accountability Journal, 9 (2), 50-67.

Deegan, C., Rankin, M., \& Tobin, J. (2002). An examination of the corporate social and environmental disclosures of BHP from 1983 1997. Accounting, Auditing \& Accountability Journal, 15 (3), 312-343.

Dowling, J., \& Pfeffer, J. (1975). Organizational Legitimacy: Social Values and Organizational Behavior between the Organizations seek to establish congruence. The Pacific Sociological Review, 18 (1),

\section{2-136.}

Elkington, J. (1998). Partnerships from Cannibals with Forks: The Triple Bottom line of 21 st Century Business. Environmental Quality Management, 8 (1), 37-51.

Esa, E., \& Anum Mohd Ghazali, N. (2012). Corporate social responsibility and corporate governance in Malaysian government linked companies. Corporate Governance: The International Journal of Business in Society, 12 (3), 292-305.

Frank, T., \& Armandi, B.R. (1981). A need - hierarchy framework for asessing Corporate Social Responsibility. Academy of Management Review, 6 (1), 21-28.

Freeman. (1984). Strategic Management: A Stakeholder Approach. Boston, USA: Pittman.

Friedman, M. (1970). A Theoretical Framework for Monetary Analysis. Journal of Political Economy, 78 (6), 193-238.

Gallardo-Vázquez, D., \& SanchezHernandez, M.I. (2014). Measuring Corporate Social Responsibility for competitive success at a regional level. Journal of Cleaner Production, 72, 14-22.

Gray, R., Javad, M., Power, D.M., \& Sinclair, C.D. (2001). Social and environmental disclosure and corporate characteristics: A research note and extension. Journal of Business Finance and Accounting, 28 (3-4), 327-356.

Gray, R., Kouhy, R., \& Lavers, S. (1995). Corporate social and environmental reporting: a review of the literature and a longitudinal study of UK disclosure. Accounting, Auditing \& Accountability Journal, 8 (2), 47-77.

Guthrie, J., \& Parker, L.D. (1989). Corporate Social Reporting: A Rebuttal of Legitimacy Theory. Accounting and Business Research, 19 (76), 343-352. 
Hackston, D., \& Milne, M. J. (1996). and environmental disclosures in New Zealand companies. Accounting, Auditing \& Accountability Journal, 9 (1), 77-108.

Haniffa, R.M., \& Cooke, T.E. (2005). The impact of culture and governance on corporate social reporting. Journal of Accounting and Public Policy, 24 (5), 391-430.

Harte, G., \& Owen, D. (1991). Environmental Disclosures: A note on reporting practices in Manland Europe. Accounting, Auditing \& Accountability Journal, 4 (3), 51-61.

Hoang, T.C., Abeysekera, I., \& Ma, S. (2016). Board Diversity and Corporate Social Disclosure: Evidence from Vietnam. Journal of Business Ethics, 1-20.

Jo, H., \& Harjoto, M.A. (2012). The Causal Effect of Corporate Governance on Corporate Social Responsibility. Journal of Business Ethics, 106 (1), 53-72.

Khan, A., Muttakin, M.B., \& Siddiqui, J. (2013). Corporate Governance and Corporate Social Responsibility Disclosures: Evidence from an Emerging Economy. Journal of Business Ethics, 114 (2), 207-223.

Lu, Y., \& Abeysekera, I. (2014). Stakeholders' power, corporate characteristics, and social and environmental disclosure: Evidence from China. Journal of Cleaner Production, 64, 426-436.

Mathews, M.R. (1997). Twenty-five years of social and environmental accounting research: Is there a silver jubilee to celebrate? Accounting, Auditing \& Accountability Journal, 10 (4), 481-531.

Milne, M.J., \& Adler, R.W. (1999). Exploring the reliability of social and environmental disclosures content analysis. Accounting, Auditing \& Accountability Journal, 12 (2), 237-256.
Neu, D., Warsame, H., \& Pedwell, K. (1998). Managing Public Impressions: Environmental Disclosures in Annual Reports. Accounting, Organizations and Society, 23 (3), 265-282.

Patten, D.M. (1991). Exposure, legitimacy, and social disclosure. Journal of Accounting and Public Policy, 10 (4), 297-308.

Reverte, C. (2009). Determinants of corporate social responsibility disclosure ratings by Spanish listed firms. Journal of Business Ethics, 88 (2), 351-366.

Robert, C.B. (1991). The Influence of External Pressure Groups on Corporate Social Disclosure Some Empirical Evidence. Accounting, Auditing \& Accountability Journal, 4 (3), 62-71.

Roberts, R.W. (1992). Determinants of corporate social responsibility disclosure: an application of stakeholder theory. Accounting, Organizations and Society, 17 (6), 595-612.

Said, R., Hj Zainuddin, Y., \& Haron, H. (2009). The relationship between corporate social responsibility disclosure and corporate governance characteristics in Malaysian public listed companies. Social Responsibility Journal, 5 (2), 212-226.

Saleh, M., Zulkifli, N., \& Muhamad, R. (2011). Looking for evidence of the relationship between corporate social responsibility and corporate financial performance in an emerging market. AsiaPacific Journal of Business Administration, 3 (2), 165-190.

Tagesson, T., Blank, V., Broberg, P., \& Collin, S.-O. (2009). What explains the extent and content of social disclosures on corporate websites? Corporate Social Responsibility and Environmental Management, 364 (March), 352-364.

Tilt, C.A. (1994). The Influence of 
External Pressure Groups on Corporate

Social Disclosure: Some Empirical

Evidence. Accounting, Auditing \&

Accountability Journal, 7 (4), 47-72.

Toms, J.S. (2002). Firm resources, quality signals and the determinants of corporate environmental reputation: Some UK evidence. British Accounting Review, 34 (3), 257-282.

Tsang, E.W.K. (1998). A longitudinal study of corporate social reporting in Singapore: The case of the banking, food and beverages and hotel industries. Accounting, Auditing \& Accountability Journal, 11 (5), 624-635.

Unerman, J. (2000). Methodological Issues Reflections on quantification in corporate social reporting content analysis. Accounting, Auditing \& Accountability Journal, 13 (5), 667-680. 